\title{
ANALISIS ANGGARAN PENGADAAN BARANG DAN JASA TERHADAP PENCAIRAN ANGGARAN PADA SEKOLAH MENENGAH KEJURUAN SMTI PADANG
}

\author{
Imron Hasan, Febryandhie Ananda \\ Sekolah Tinggi Ilmu Ekonomi KBP \\ email: imronhasan24@gmail.com \\ febryandhie@akbpstie.ac.id
}

\begin{abstract}
The structure of the State Revenue and Expenditure Budget is the supportive government spending in the development of community welfare reflected in capital expenditure or disbursement of the budget. The realization of the budget in the country has always been an issue that happens every year. Efforts have been made to optimize the realization of the state budget, but the facts show that no significant change has been made regarding the realization of the budget. To drive the acceleration of budget realization, the government has prepared several strategic steps that is the acceleration of procurement of goods. Procurement of goods and services at Vocational High School SMTI Padang is the main duty of the existence of agency not to produce goods aimed at profit oriented, but rather provide services to the public that is educational facilities.This research aims to analyze the effect of budget procurement of goods on the realization of disbursement of Vocational High School SMTI Padang. Sources of data used in this research is secondary data The research method used is a quantitative method with a simple linear regression analysis. In this research using independent variables $(X)$ that is the procurement of goods and the dependent variable $(Y)$ is the realization of disbursement and absorption of the budget. there is a significant influence between the procurement budget of goods on the realization of budget disbursement in Vocational High School SMTI Padang, which means that the increasing budget realization of procurement of goods will be followed by the increase of budget realization, it is shown from t test result obtained t count 31,872 with value significance of $0.000<0.05$.
\end{abstract}

Keywords: Budget Realization; Procurement of goods.

\section{PENDAHULUAN}

Struktur Anggaran Pendapatan dan Belanja Negara (APBN) yaitu pengeluaran pemerintah yang mendukung dalam pembangunan kesejahteraan masyarakat tercermin dalam belanja modal atau pencairan anggaran. Penyerapan anggaran sebagai pencapaian kinerja memiliki fungsi sebagai alat perencanaan dan sebagai alat pengendalian. Anggaran sebagai alat perencanaan mengindikasikan target yang harus dicapai oleh organisasi/instansi pemerintah, sedangkan anggaran sebagai alat pengendalian memberikan alokasi sumber dana publik yang disetujui oleh Dewan Perwakilan Rakyat (DPR) untuk dibelanjakan. Penyerapan anggaran yang optimal dan sesuai dengan perencanaan anggaran akan terciptanya kegiatan perekonomian yang berjalan sesuai dengan seharusnya, tetapi jika terjadi keterlambatan secara ekonomi akan menyebabkan kerugian negara. Pelaksanaan APBN hampir dipastikan bahwa setiap triwulan III dan triwulan IV tahun anggaran berjalan terjadi peningkatan tajam pencairan dan penyerapan anggaran, trennya adalah pada triwulan IV selalu melonjak dengan drastis.

Untuk mendorong percepatan realisasi dan penyerapan anggaran, pemerintah telah menyiapkan beberapa langkah strategis. Langkah-langkah tersebut antara lain 
dengan usaha peningkatan kemampuan teknis para pengelola keuangan satuan kerja dalam menyusun perencanaan pengadaan dan rencana penarikan belanja di setiap Kementerian/Lembaga, di samping itu pemerintah telah menerbitkan Peraturan Presiden Nomor 54 Tahun 2010 untuk mendukung percepatan proses pengadaan barang dan jasa dengan menggunakan sistem online.

Pengadaan barang dan jasa di Sekolah Menengah Kejuruan SMTI Padang (SMK SMTI Padang) adalah tugas pokok keberadaan instansi bukan untuk menghasilkan barang dan jasa yang bertujuan untuk mencari keuntungan (profit oriented), namun lebih bersifat memberikan pelayanan kepada masyarakat berupa fasilitas pendidikan, maka dari itu SMK SMTI Padang membutuhkan barang dan jasa dalam rangka meningkatkan pelayanan publik khususnya untuk menunjang proses pembelajaran.

Menurut (Garrison \& Norren, 2000) anggaran adalah rencana rinci tentang pendapatan dan penggunaan sumber daya keuangan dan sumber daya lainnya untuk suatu periode tertentu. Anggaran merupakan salah satu hal penting suatu organisasi dalam mencapai tujuannya. Anggaran merupakan sarana utama untuk perencanaan, pengendalian dan pengambilan keputusan dalam setiap organisasi atau instansi. Rencana organisasi ini biasanya mencakup berbagai kegiatan operasional yang saling berkaitan dan saling mempengaruhi dengan sistem pendekatan formal dan terukur dari pelaksanaan tanggungjawab manajemen dalam perencanaan, koordinasi dan pengendalian suatu anggaran. Berdasarkan Pasal 14 ayat (6) Undang-Undang Nomor 17 Tahun 2003 telah disusun peraturan perundang-undangan yang didalamnya tertulis tentang mengatur penyusunan rencana kerja (renja) dan anggaran kementerian negara atau lembaga pemerintah.

Menurut (Mardiasmo, 2009) kinerja manajer publik akan dinilai berdasarkan pencapaian target anggaran yaitu dihitung penyerapan anggaran yang berhasil dicapai. Penilaian kinerja dilakukan dengan menganalisis simpangan kinerja aktual dengan yang dianggarkan. Belanja pemerintah merupakan salah satu elemen untuk menjaga pertumbuhan ekonomi suatu negara. Belanja pemerintah, khususnya belanja barang dan jasa merupakan salah satu komponen utama yang membentuk Produk Domestik Bruto (PDB) atau Gross Domestic Product (GDP).

Fungsi anggaran pada suatu organisasi atau instansi merupakan alat untuk membantu manajemen dalam pelaksanaan, perencanaan, koordinasi, pengawasan dan juga sebagai pedoman kerja dalam menjalankan suatu organisasi untuk tujuan yang telah ditetapkan. Menurut (Supriyono, 1999) fungsi anggaran meliputi:
a. fungsi perencanaan
b. fungsi koordinasi
c. fungsi komunikasi
d. fungsi motivasi
e. fungsi pengendalian dan evaluasi
f. fungsi pendidik

Menurut (LKPP, 2010) dalam modul Pengantar Pengadaan Barang/Jasa di Indonesia mendeskripsikan pengadaan barang dimulai sejak adanya pasar dimana orang dapat membeli dan menjual dengan cara tawar menawar secara langsung antara pihak pembeli (pengguna barang/jasa) dengan pihak penjual (penyedia barang/jasa) hingga tercapai kesepakatan harga kemudian dilanjutkan dengan transaksi jual beli. Transaksi jual beli dapat diartikan sebagai kondisi dimana pihak penyedia barang menyerahkan barang kepada pihak pengguna dan pihak pengguna membayar berdasarkan harga yang 
disepakati kedua belah pihak. Menurut (Perpres No. 54, 2010) pengadaan barang dan jasa meliputi pengadaan barang, pekerjaan konstruksi, jasa konsultansi dan jasa lainnya. Menurut (Mukmin, 1992) dalam bukunya pengadaan barang dan jasa, menjelaskan pengadaan adalah segala usaha dan kegiatan untuk memenuhi kebutuhan terhadap barang dan jasa dalam batas peraturan perundang-undangan yang berlaku. Menurut Keppres No 54 Tahun 2010 menjelaskan pengadaan barang dan jasa merupakan suatu kegiatan pengadaan dalam hal untuk mendapatkan barang dan jasa.

Penelitian (Putri, 2014) menemukan bahwa kompetensi sumber daya manusia (SDM), dokumen pengadaan dan uang persediaan memiliki pengaruh yang signifikan terhadap penyerapan anggaran. Penelitian (Adi Priatno, 2013) menunjukkan bahwa faktor perencanaan dan faktor pengadaan barang dan jasa mempunyai pengaruh yang signifikan terhadap penyerapan anggaran.

\section{METODE PENELITIAN}

Data penelitian ini bersumber dari data sekunder yang diperoleh peneliti secara tidak langsung melalui media perantara. Data sekunder dalam penelitian ini diperoleh dari laporan keuangan, media elektronik dan literatur mengenai permasalahan pencairan anggaran pengadaan barang dan jasa.

Objek dari penelitian ini menitikberatkan kepada pencairan anggaran pengadaan barang dan jasa terhadap realisasi anggaran di sebuah organisasi pemerintah yaitu Sekolah Menengah Kejuruan SMTI Padang yang berlokasi di Jalan Ir. H. Juanda No. 2 Kelurahan Rimbo Kaluang Kecamatan Padang Barat Kota Padang Kode Pos 25115.

Jenis penelitian ini adalah menggunakan metode kuantitatif. Metode kuantitatif dapat diartikan sebagai metode penelitian yang berlandaskan pada filsafat positivisme, digunakan untuk meneliti pada populasi atau sampel tertentu, pengumpulan data menggunakan instrumen penelitian, analisis data bersifat kuantitatif atau statistik dengan tujuan untuk menguji hipotesis yang telah ditetapkan (Sugiyono, 2016).

Berdasarkan latar belakang dan kerangka pemikiran yang dikemukakan pada bab sebelumnya, maka yang menjadi variabel penelitian ini adalah variable independen $(\mathrm{X})$ yaitu anggaran pengadaan barang dan jasa dan variable dependen (Y) yaitu realisasi penyerapan anggaran di SMK SMTI Padang.

Teknik analisis data suatu metode atau cara untuk mengolah sebuah data menjadi informasi sehingga karakteristik data tersebut menjadi mudah untuk dipahami dan juga bermanfaat untuk menemukan solusi permasalahan, yang tertutama adalah masalah yang tentang sebuah penelitian. Analisis data penelitian ini menggunakan uji normalitas data digunakan untuk mengetahui normal tidaknya masing-masing variabel penelitian. Uji normalitas residual dilakukan dengan menggunakan kolmogorov-smirnov test dengan taraf signifikan $5 \%$.

Uji F pada dasarnya menunjukkan apakah semua variabel independen berpengaruh secara bersama-sama terhadap variabel dependen, kriteria pengujian berdasarkan probabilitas, jika probabilitas signifikansi lebih besar dari 0,05 ( $\alpha$ ), maka variabel independen tidak berpengaruh terhadap variabel dependen, jika lebih kecil dari 0,05 maka variabel independen berpengaruh terhadap variabel dependen.

Uji t pada dasarnya menunjukkan seberapa besar pengaruh satu variabel independen secara individual dalam menerangkan variasi variabel dependen. Menurut (Ghozali, 2016) kriteria pengujian dilakukan berdasarkan probabilitas signifikansi lebih kecil dari 0,05 $(\alpha)$, maka variabel independen secara individu berpengaruh terhadap terhadap variabel dependen, namun jika probabilitas signifikansi lebih besar dari 0,05 $(\alpha)$, 
maka variabel independen secara individu tidak berpengaruh terhadap terhadap variabel dependen.

Uji koefisien determinasi $\left(\mathrm{R}^{2}\right)$ digunakan untuk mengetahui seberapa besar varian dari variabel dependen dapat dijelaskan oleh variabel independen. Bila nilai koefisien determinasi sama dengan $0\left(\mathrm{R}^{2}=0\right)$, artinya variasi dari $\mathrm{Y}$ tidak dapat diterangkan oleh $\mathrm{X}$ sama sekali, sementara bila $\mathrm{R}^{2}=1$, artinya variasi dari $\mathrm{Y}$ secara keseluruhan dapat diterangkan oleh X (Ghozali, 2016).

Analisis regresi linear sederahana adalah hubungan secara linear antara satu variabel independen $(\mathrm{X})$ dengan variabel dependen $(\mathrm{Y})$. Analisis ini untuk mengetahui arah hubungan antara variabel independen dengan variabel dependen apakah positif atau negatif dan untuk memprediksi nilai dari variabel dependen apabila nilai variabel independen mengalami kenaikan atau penurunan.

\section{HASIL DAN PEMBAHASAN}

Sekolah Menengah Kejuruan SMTI Padang pada awal berdirinya bernama Sekolah Teknologi Menengah Atas (STMA) dengan program pendidikan 4 (empat) tahun. Sekolah ini didirikan pada tanggal 7 Februari 1967 atas prakarsa alumni STMA Yogyakarta. Pada tahun 1985 melalui Surat Keputusan Menteri Perindustrian No : 235/M/SK/1985, tanggal 25 Juli 1985 mengalami perubahan nama dari Sekolah Teknologi Menengah Atas (STMA) menjadi Sekolah Menengah Teknologi Industri yang disingkat SMTI, dengan program 3 (tiga) tahun dan memiliki 1 (satu) jurusan yaitu kimia industri. Berdasarkan peraturan Menteri Perindustrian RI, No : 77/M-IND/PER.8/2011, tanggal 12 Agustus 2011 tentang Organisasi dan Tata Kerja Sekolah, nama SMTI Padang nomenklaturnya berubah menjadi Sekolah Menengah Kejuruan SMTI Padang.

Laporan realisasi anggaran menggambarkan perbandingan antara anggaran dengan realisasinya yang mencakup unsur-unsur pendapatan dan belanja selama periode Januari - Desember di tahun berjalan. Ringkasan laporan realisasi anggaran dapat dilihat pada tabel dibawah ini:

Tabel 1.

Realisasi Anggaran

\begin{tabular}{|c|c|c|c|c|c|c|}
\hline \multirow[b]{2}{*}{ No. } & \multirow[b]{2}{*}{ Tahun } & \multirow[b]{2}{*}{ Pagu Anggaran } & \multicolumn{4}{|c|}{ Realisasi } \\
\hline & & & $\begin{array}{c}\text { Triwulan } \\
\text { I }\end{array}$ & $\begin{array}{c}\text { Triwulan } \\
\text { II }\end{array}$ & $\begin{array}{c}\text { Triwulan } \\
\text { III }\end{array}$ & $\begin{array}{c}\text { Triwulan } \\
\text { IV }\end{array}$ \\
\hline 1. & 2016 & Rp. 13.825.051.000 & $12,92 \%$ & $34,54 \%$ & $63,39 \%$ & $96,23 \%$ \\
\hline 2. & 2017 & Rp. 11.464.560.000 & $21,30 \%$ & $49,08 \%$ & $69,76 \%$ & $95,93 \%$ \\
\hline
\end{tabular}

Sumber : SMK SMTI Padang (2017)

Pengadaan barang dan jasa di SMK SMTI Padang terbagi atas 3 (tiga) pengadaan, yang terdiri dari:

a. belanja layanan internal

b. belanja layanan perkantoran serta sarana dan prasarana

c. belanja jasa pendidikan dan pelatiha bagi SDM industri.

Realisasi pengadaan barang dan jasa di SMK SMTI Padang dapat dilihat pada tabel ringkasan realisasi pengadaan barang dan jasa berikut ini: 
Tabel 2.

Realisasi Anggaran Pengadaan Barang dan Jasa

\begin{tabular}{|c|c|c|c|c|c|c|}
\hline & \multirow{2}{*}{ No. } & \multirow{2}{*}{$\begin{array}{c}\text { Tahu } \\
\mathbf{n}\end{array}$} & \multirow{2}{*}{ Realisasi Anggaran } & \multicolumn{4}{|c|}{ Realisasi Pengadaan Barang dan Jasa } \\
\cline { 4 - 7 } & & & $\begin{array}{c}\text { Triwulan } \\
\text { I }\end{array}$ & $\begin{array}{c}\text { Triwulan } \\
\text { II }\end{array}$ & $\begin{array}{c}\text { Triwulan } \\
\text { III }\end{array}$ & $\begin{array}{c}\text { Triwulan } \\
\text { IV }\end{array}$ \\
\hline 1. & 2016 & Rp. 13.303.846.577 & $8,75 \%$ & $26,32 \%$ & $50,38 \%$ & $72,27 \%$ \\
\hline 2. & 2017 & Rp. 10.997 .952 .408 & $16,88 \%$ & $38,39 \%$ & $57,87 \%$ & $77,35 \%$ \\
\hline
\end{tabular}

Sumber : SMK SMTI Padang (2017)

Laporan keuangan SMK SMTI Padang merupakan laporan yang mencakup seluruh aspek keuangan yang dikelola oleh SMK SMTI Padang. Laporan Keuangan dihasilkan melalui Sistem Akuntansi Instansi (SAI) yaitu serangkaian prosedur manual maupun yang terkomputerisasi mulai dari pengumpulan data, pencatatan dan pengikhtisaran sampai dengan pelaporan posisi keuangan dan operasi keuangan pada Kementerian Negara/Lembaga. SAI terdiri dari Sistem Akuntansi Instansi Berbasis Akrual (SAIBA) dan Sistem Informasi Manajemen dan Akuntansi Barang Milik Negara (SIMAK-BMN). Pendekatan penyusunana laporan keuangan di SMK SMTI Padang menggunakan pendekatan yang dijelaskan sebagai berikut:
a. Basis Akuntansi
b. Dasar Pengukuran
c. Kebijakan Akuntansi

Statistik deskriptif menggambarkan tentang ringkasan data-data penelitian seperti mean, standar deviasi, varian, modus dan lain sebagainya. Output tampilan SPSS menunjukan jumlah data $(\mathrm{N})$ ada 8 (delapan) data yaitu realisasi penyerapan anggaran mulai dari triwulan I sampai dengan triwulan IV tahun anggaran 2016 serta triwulan I sampai dengan IV tahun anggaran 2017. Data realisasi penyerapan anggaran terkecil yaitu $11,66 \%$ dan realisasi terbesar yaitu $94,35 \%$ dengan rata-rata realisasi anggaran sebesar $55,33 \%$ dengan standar deviasi sebesar 31,48.

Tabel 3.

Hasil Analisis Uji Deskriptif

\begin{tabular}{|c|c|c|c|c|c|}
\hline & Minimum & Maximum & Mean & Std. Deviation & N \\
\hline Predicted Value & 11,9116 & 97,6850 & 55,3938 & 31,57774 & 8 \\
\hline
\end{tabular}

Uji normalitas adalah sebuah uji yang dilakukan dengan tujuan untuk menilai sebaran data pada sebuah kelompok data atau variabel, apakah sebaran data tersebut berdistribusi normal ataukah tidak. Hasil uji normalitas diatas adalah nilai signifikansi 0,200 lebih besar dari 0,05 sehingga dapat disimpulkan bahwa data yang di uji berdistribusi normal. 
Tabel 4.

Hasil Uji Normalitas

One-Sample Kolmogorov-Smirnov Test

\begin{tabular}{|l|r|}
\hline & \multicolumn{1}{|c|}{ Standardized Residual } \\
\hline N & 8 \\
\hline Asymp. Sig. (2-tailed) &, $200^{\mathrm{c}, \mathrm{d}}$ \\
\hline
\end{tabular}

a. Test distribution is Normal.

Uji autokorelasi bertujuan untuk melihat apakah dalam sebuah model regresi linear terdapat korelasi antara kesalahan pengganggu pada periode $t$ dengan kesalahan pengganggu periode 1-t pada data yang tersusun dalam rangkaian waktu (time series). Hasil uji autokorelasi dapat dilihat pada tabel sebagai berikut:

Tabel 5

Hasil Uji Autokorelasi

\begin{tabular}{|c|c|}
\hline Durbin Watson Test $(\mathbf{D W})$ & Hasil \\
\hline 1,928 & Tidak Ada Autokorelasi \\
\hline
\end{tabular}

Uji statistik F pada dasarnya menunjukkan apakah semua variabel independen berpengaruh secara bersama-sama terhadap variabel dependen. Berdasarkan hasil perhitungan uji $\mathrm{F}$ pada Tabel 4.7 diperoleh $\mathrm{F}_{\text {hitung sebesar 1015,829 dengan probabilitas }}$ $0,000<0,05$ maka dapat disimpulkan bahwa persamaan garis tersebut linear dan signifikan, sehingga terdapat pengaruh antara anggaran pengadaan barang dan jasa terhadap realisasi pencairan anggaran.

Tabel 6.

Hasil Uji F

ANOVA $^{\mathrm{a}}$

\begin{tabular}{|c|l|l|l|l|}
\hline \multicolumn{2}{|c|}{ Model } & \multicolumn{1}{c|}{ Df } & F & \multicolumn{1}{c|}{ Sig. } \\
\hline \multirow{3}{*}{1} & Regression & 1 & 992,723 &, $000^{\mathrm{b}}$ \\
\cline { 2 - 6 } & Residual & 6 & & \\
\cline { 2 - 6 } & Total & 7 & & \\
\hline
\end{tabular}

a. Dependent Variable: Realisasi_Anggaran

Uji t merupakan teknik analisis untuk membandingkan satu variabel bebas. Uji ini digunakan untuk menguji apakah nilai tertentu berbeda secara signifikan atau tidak dengan rata-rata sebuah sampel. Diperoleh nilai konstanta sebesar 0,974, berdasarkan hasil pengujian diatas juga diperoleh koefisien untuk realisasi anggaran pengadaan barang dan jasa sebesar 0,992 dengan $t_{\text {hitung }}=31,872$ dengan signifikansi $0,000<0,05$. Hal ini berati dapat disimpulkan ada pengaruh realisasi anggaran pengadaan barang dan jasa terhadap realisasi pencairan anggaran. 
Tabel 6.

Hasil Uji t

Coefficients $^{\mathrm{a}}$

\begin{tabular}{|c|l|l|l|}
\hline \multicolumn{2}{|c|}{ Model } & \multicolumn{1}{c|}{ T } & \multicolumn{1}{c|}{ Sig. } \\
\hline 1. & Realisasi_Pengadaan & 31,508 &, 000 \\
\hline
\end{tabular}

a. Dependent Variable: Realisasi_Anggaran

Berdasarkan hasil perhitungan SPSS dapat dilihat nilai $\mathrm{R}^{2}$ sebesar 0,994. Hal ini berati $99,4 \%$ variasi perubahan realisasi pencairan anggaran dijelaskan oleh variasi perubahan faktor-faktor anggaran pengadaan barang dan jasa, sementara sisanya sebesar $0,6 \%$ diterangkan oleh faktor lain

Tabel 7.

Hasil Uji R ${ }^{2}$

Model Summary ${ }^{\mathrm{b}}$

\begin{tabular}{|r|r|r|r|}
\hline Model & \multicolumn{2}{|c|}{ R } & \multicolumn{2}{|c|}{ R Square } & \multicolumn{2}{|c|}{ Adjusted R Square } \\
\hline 1 &, $997^{\mathrm{a}}$ &, 994 &, 993 \\
\hline
\end{tabular}

a. Dependent Variable: Realisasi_Anggaran

Menurut (Ghozali, 2016) secara umum koefisien determinasi untuk data silang (crosssection) relatif rendah, sedangkan untuk data runtun waktu (time series) biasanya mempunyai nilai koefisien determinasi yang tinggi. Peneliti (Juliani \& Sholihin, 2014) yang berjudul pengaruh faktor-faktor kontekstual terhadap persepsian penyerapan anggaran terkait pengadaan barang/jasa mengatakan bahwa penyerapan anggaran tidak hanya ditinjau dari realisasi nominal atau persentase penyerapan anggaran terkait pengadaan barang dan jasa yang terdapat pada laporan realisasi anggaran, tetapi juga ditinjau dari bagaimana persepsi pengguna anggaran untuk mencapai target anggaran. Penyerapan anggaran terkait pengadaan barang dan jasa merupakan proses merealisasikan anggaran belanja pemerintah secara efektif dan efisien sesuai dengan target dan capaian anggaran dalam pengadaan barang dan jasa pemerintah.

Hasil analisis penelitian menunjukkan bahwa ada pengaruh yang signifikan antara anggaran pengadaan barang dan jasa terhadap realisasi pencairan anggaran di SMK SMTI Padang baik secara simultan maupun parsial yang dibuktikan dari hasil uji $\mathrm{F}$ yang diperoleh besar signifikansi $0,000<0,05$ dan secara parsial yang dibuktikan dengan uji t yang diperoleh besar signifikansi $0,000<0,05$. Berdasarkan persamaan regresi yang diperoleh dimana koefisien regresi bertanda positif, maka dapat diartikan bahwa terdapat pengaruh positif anggaran pengadaana barang dan jasa terhadap realisasi pencairan anggaran dengan besarnya pengaruh secara simultan sebesar 99,4\%, sedangkan $0,6 \%$ dipengaruhi oleh faktor-faktor lain yang tidak dikaji dalam penelitian ini.

Hasil penelitian ini mendukung penelitian (Putri, 2014) yang membuktikan bahwa kompetensi sumber daya manusia, uang persediaan dan dokumen perencanaan pengadaan barang dan jasa memiliki pengaruh signifikan terhadap penyerapan anggaran di SKPD Pemerintah Provinsi Bengkulu. Begitu juga penelitian (Adi Priatno, 2013) memberikan hasil bahwa perencanaan anggaran dan pengadaan barang dan jasa memiliki pengaruh 
signifikan terhadap penyerapan anggaran pada satuan kerja lingkup pembayaran KPPN Blitar. Peneliti lain yang penelitiannya tentang penyerapan anggaran yaitu (Gagola, 2017) dengan hasil penelitian menunjukkan bahwa secara simultan maupun parsial perencanaan anggaran, pelaksanaan anggaran, pengadaan barang jasa, komitmen manajemen dan lingkungan birokrasi berpengaruh positif dan signifikan terhadap penyerapan anggaran pendapatan dan belanja daerah (APBD) Pemerintah Kabupaten Kepulauan Talaud.

Berdasarkan uraian di atas dapat disimpulkan bahwa pengadaan barang dan jasa berpengaruh terhadap realisasi pencairan atau penyerapan anggaran khususnya di Sekolah Menengah Kejuruan SMTI Padang. Oleh karena itu dalam upaya untuk meningkatkan penyerapan anggaran diharapkan dapat memberikan perhatian yang serius terhadap permasalahan penyerapan anggaran, dengan cara terus memperbaiki proses perencanaan anggaran mulai dari penyusunan RKA-KL sampai dengan penetapan APBN serta melakukan proses pengadaan barang jasa sesuai dengan peraturan perundangundangan yang berlaku.

\section{SIMPULAN}

Berdasarkan hasil pengamatan dan analisis data dengan bantuan SPSS 23 for windows, maka dapat dikemukakan kesimpulan dari hasil penelitian ini yaitu adanya pengaruh signifikan antara anggaran pengadaan barang dan jasa terhadap realisasi pencairan anggaran di Sekolah Menengah Kejuruan SMTI Padang, yang berarti semakin meningkat realisasi anggaran pengadaan barang dan jasa akan diikuti dengan kenaikan realisasi penyerapan anggaran, hal ini ditunjukkan dari hasil uji t diperoleh $t_{\text {hitung }} 31,508$ dengan nilai signifikansi yaitu $0.000<0.05$.

Saran yang diberikan pada penelitian ini adalah Penelitian ini menggunakan anggaran belanja Sekolah Menengah Kejuruan SMTI Padang secara total, tidak dirinci menurut jenis belanja, karena penulis kesulitan dalam melakukan pengumpulan data. Untuk penelitian selanjutnya, peneliti menyarankan untuk melakukan penelitian tentang penyerapan anggaran dengan dirinci berdasarkan jenis belanjanya.

\section{UCAPAN TERIMA KASIH}

Puji syukur penulis panjatkan kepada Tuhan Yang Maha Esa karena atas rahmat dan karunia-Nya sehingga penulis dapat menyelesaikan skripsi ini sesuai dengan waktu yang direncanakan.

Pada kesempatan ini, penulis ingin menyampaikan rasa terima kasih yang sebesarbesarnya kepada semua pihak yang telah membantu penulis dalam menyelesaikan penulisan skripsi ini dalam bentuk bantuan moril maupun materiil, yaitu:

1. Bapak Febryandhie Ananda, SE, M.Si selaku Ketua STIE KBP sekaligus dosen pembimbing yang telah membimbing serta meluangkan waktunya untuk membantu penulis menyelesaikan skripsi ini serta memberikan saran dan masukan yang sangat berarti dalam penulisan skripsi ini.

2. Ibu Dewi Zulvia, SE, MM. selaku ketua program studi akuntasi STIE KBP yang secara administratif telah menunjang terlaksananya penulisan skripsi ini.

3. Segenap dosen dan staf program studi akuntansi yang dengan tulus memberikan ilmu pengetahuan selama perkuliahan di STIE KBP Padang

4. Tenaga Pendidik dan Kependidikan Sekolah Menengah Kejuruan SMTI Padang yang telah membantu penulis untuk mengumpulkan data sebagai bahan penyusunan skripsi. 


\section{DAFTAR PUSTAKA}

Adi Priatno, P. (2013). Analisis Faktor-Faktor yang Mempengaruhi Penyerapan Anggaran Pada Satuan Kerja Lingkup Pembayaran KPPN Blitar.

Badan Pendidikan dan Pelatihan Keuangan. (2016). Perhitungan uang persediaan 1. Perhitungan Uang Persediaan. Retrieved from https://klc.kemenkeu.go.id/wpcontent/uploads/2016/10/BP_APBN-II-1.-Modul-KB-1.pdf

Direktorat Jenderal Perbendaharaan. (2010). Prosedur Pencairan Dana APBN. Retrieved from http://www.djpbn.kemenkeu.go.id/portal/id/layanan/kppn/pencairandana.html

Djoko Luknanto. (2010). Modul Kebijakan \& Ketentuan Umum Pengadaan Barang/Jasa. Yogyakarta. Retrieved from www.luk.staff.ugm.ac.id/phk/

Gagola, L. (2017). ANALISIS FAKTOR-FAKTOR YANG MEMPENGARUHI PENYERAPAN ANGGARAN PENDAPATAN DAN BELANJA DAERAH (APBD) PEMERINTAH KABUPATEN KEPULAUAN TALAUD. JURNAL RISET AKUNTANSI DAN AUDITING “GOODWILL, ”Vol 8, No.

Garrison, \& Norren. (2000). Akuntansi Manajerial (terjemahan : A. Totok Budisantoso).

(T. Budi Santoso, Ed.) (Edisi I). Jakarta: Salemba Empat.

Ghozali, I. (2016). Aplikasi Analisis Multivariete Dengan Program IBM SPSS 23. Semarang: Badan Penerbit UNDIP.

Herriyanto. (2012). Faktor-Faktor yang Mempengaruhi Keterlambatan Penyerapan Anggaran Belanja pada Satuan Kerja Kementerian/Lembaga di Wilayah Jakarta. Thesis.

Juliani, D., \& Sholihin, M. (2014). Pengaruh Faktor-Faktor Kontekstual Terhadap Persepsian Penyerapan Anggaran Terkait Pengadaan Barang/Jasa. Jurnal Akuntansi Dan Keuangan Indonesia, 11(2). https://doi.org/10.21002/jaki.2014.10

Keputusan Presiden No. 80. (2003).

Kuncoro. (2013). Mudah Memahami dan Menganalisis Indikator Ekonomi. Yogyakarta: UPP STIM YKPN.

LKPP. (2010). Modul Pengantar Pengadaan Barang Dan Jasa di Indonesia.

Lubis, A. S. (2010). PROSEDUR PENCAIRAN ANGGARAN BELANJA NEGARA.

Retrieved from http://www.bppk.kemenkeu.go.id/publikasi/artikel/147-artikelanggaran-dan-perbendaharaan/13395-prosedur-pen cairan-anggaran-belanja-negara Mardiasmo. (2009). Akuntansi Sektor Publik. Yogyakarta: ANDI.

Mulyadi. (1997). Akuntansi Manajemen: Konsep, Manfaat dan Rekayasa (Edisi 8). Yogyakarta: STIE YKPN.

Perpres No. 54. (2010). Tentang Pengadaan Barang dan Jasa.

Putri, C. T. (2014). Analisis Faktor-Faktor yang Mempengaruhi Penyerapan Anggaran pada Satuan Kerja Perangkat Daerah di Pemerintah Provinsi Bengkulu.

Sugiyono. (2016). Metode Penelitian Kuantitatif, Kualitatif dan R\&D (Edisi 23). Bandung: ALFABETA, CV.

Supriyono. (1999). Akuntansi Biaya: Perencanaan dan Pengendalian Biaya Serta 
Pembuatan Keputusan (Buku II). Yogyakarta: BPFE-UGM.

Undang-Undang Dasar 1945 Pasal 23 Ayat 1. (2001). UUD 1945 Perubahan Ketiga. UNDANG-UNDANG RI NOMOR 25 TAHUN 2004. (2004). 